\title{
A taxonomic study of the Spirillum lipoferum group, with descriptions of a new genus, Azospirillum gen. nov. and two species, Azospirillum lipoferum (Beijerinck) comb. nov. and Azospirillum brasilense sp. nov.
}

\author{
JefFrey J. Tarrand and Noel R. Krieg \\ Departmem of Biology, Virginia Polytechnic Institute and State University, Blacksburg, VA, U.S.A. 24061 \\ AND \\ JOHANNA DÖBEREINER \\ Empresa Brasileira de Pesquisa Agropecuairia, Km 47, 23460 Seropédica, Rio de Janeiro, Brazil \\ Accepted April 25, 1978
}

TARRAND, J. J., N. R. KRIEg, and J. DöBEREINER, 1978. A taxonomic study of the Spirillam lipoferum group, with descriptions of a new genus, Azospirillum gen. nov. and two species, Azospirillum lipoferwm (Beijerinck) comb. nov. and Azospirillum brasilense sp. nov. Can. J. Microbiol. 24: $967-980$.

Sixty-one strains of the root-associated nitrogen fixer Spirillum lipofertum exhibited a similar morphology in peptone - succinate salts medium: vibrioid cells having a diameter of $1.0 \mu \mathrm{m}$. When grown in broth the cells had a single polar flagellum, but when grown on agar at $30^{\circ} \mathrm{C}$ lateral flagella of shorter wavelength were also formed. The DNA base composition was 69-71 mol \% guanine + cytosine when determined by thermal denaturation. DNA homology experiments indicated the occurrence of two distinct but related homology groups: 46 strains were in group I and 15 strains were in group II. Group II strains were distinguished by their ability to use glucose as at sole carbon source for growth in nitrogen-free medium, by their production of an acidic reaction in a peptone-based glucose medium, by their requirement for biotin, and by their formation of wider, longer, S-shaped or helical cells in semisolid nitrogen-free malate medium. The results indicate that two species exist, and on the basis of their characteristics it is proposed that they be assigned to a new genus, Azospirillum. Strains belonging to group II are named $\boldsymbol{A}$. lipoferum (Beijerinck) comb. nov., while those belonging to group I are named $A$. brasilense sp. nov. Strain Sp 59b (A TCC 29707) is proposed as the neotype strain for $A$. lipoferum, and strain Sp 7 (ATCC 29145) is proposed as the type strain for $A$. brasilense.

Tarrand, J. J., N. R. Krieg et J. Döberejner. 1978. A taxonomic study of the Spirillum lipoferum group, with descriptions of a new genus, Azospirillum gen. nov. and two species, Azospirillum lipoferwm (Beijerinck) comb. nov. and Azospirillum brasilense sp. nov. Can. J. Microbiol. 24: 967-980.

Soixante et une espèces de Spirillum lipoferum associées aux racines et fixatrices d’azote présentent des morphologies semblables dans les milieux minéraux avec du succinate et la peptone; les cellules ont la forme de vibrion avec un diamètre de $1 \mu \mathrm{m}$. Lorsque les cellules se développent dans des bouillons, elles possèdent un seul flagelle polaire; par' contre sur lá gélose à $30^{\circ} \mathrm{C}$ elles présentent aussi un flagelle latéral plus court. La composition de l'ADN est de 69 à $71 \%$ de guanine + cytosine. Des expériences sur l'homologie de l'ADN indiquent la présence de deux groupes homologues distincts, mais présentant une parenté: 46 espèces ont été classées dans le groupe I et 15 dans le groupe II. Les espèces du groupe II sont différenciées par leur capacité d'utiliser le glucose comme seule source de carbone pour la croissance dans un milieu sans azote, par la production d'une réaction acidique sur un milieu à base de glucose et de peptone, par leur besoin en biotine et par la formation sur un milieu malate semi-solide sans azote, de cellules en forme de $S$ ou d'hélice plus larges et plus longues. Les résultats montrent qu'il existe deux espèces, et d'après leur caractéristiques nous proposons de les classer dans un nouveau genre: Azospirillum. Les espèces appartenant au groupe II sont désignées A. lipoferum (Beijerinck) comb. nov. . tandis que celles appartenant au groupe I sont désignées $A$. brasilense $\mathrm{sp}$. nov. L'espèce $\mathrm{Sp}$ 59b (A TCC 29707) est désignée comme le néotype de $A$, lipoferum et l'espèce Sp 7 (A TCC 29 145) est désignée comme le représentant typique de $A$. brasilense.

[Traduit par le journal]

\section{Introduction}

The bacterium known as Spirillum lipoferum was first described by Beijerinck (1922, 1925). Except for a few scattered reports (Becking 1963; Schröder 1932; G. Giesberger 1936, Ph.D. Dissertation, Utrecht Univ., Netherlands) relatively little atten- tion was given to this organism until 1974 when Döbereiner and Day (1976) isolated it from the roots of certain tropical grasses in Brazil. The root pieces exhibited nitrogenase activity as indicated by acetylene reduction, and the nitrogen-fixing ability of the plants has since been confirmed by dem- 
onstrating incorporation of ${ }^{15} \mathrm{~N}_{2}$ into the plant tissue (De-Polli et al. 1977). Since 1974 S. lipoferum has been isolated from the roots of a variety of forage grasses, legumes, grain crops, and soils (Döbereiner et al. 1976; Kumari et al. 1976; Von Bülow and Döbereiner 1975). The organism is Gram-negative, motile, generally vibrioid in shape, and contains poly- $\beta$-hydroxybutyrate (PHB) granules (Döbereiner and Day 1976; Okon et al. $1976 a, 1976 b$ ). When growing in N-free media it seems microaerophilic because of a lack of oxygen-protection mechanisms for its nitrogenase (Day and Döbereiner 1976; Döbereiner 1977; Döbereiner and Day 1976; Okon et al. 1976a). In continuous culture an increased oxygen supply increases nitrogen fixation and growth provided that the oxygen in solution in the medium does not exceed $2.5 \mu M$ (M. A. T. Vargas and R. F. Harris 1977. International Symposium on Limitations and Potentials of Biological Nitrogen Fixation in the Tropics. Summary of Papers. Univ. of Brasilia, Brazil, p. 115). When supplied with fixed nitrogen $S$. lipoferum grows as an aerobe (Okon et al. 1976a). The salts of organic acids such as malate, succinate, lactate, and pyruvate have been found to be satisfactory oxidizable carbon and energy sources (Okon et al. 1976a, b). Certain strains were found to require low levels of yeast extract for growth in mineral media (Döbereiner et al. 1976; Okon et $a l .1976 a$ ) and to grow on glucose as the carbon source, whereas strains that did not require yeast extract failed to grow on glucose. Based on these and several other observations the existence of two or possibly three groups of organisms within the species $S$. lipoferum was proposed by several authors (Krieg 1977; Krieg and Tarrand 1978; Neyra et al. 1977; Okon et al. 1976a; M. J. Sampaio, L. de Vasconcellos, and J. Döbereiner. 1976. International Symposium on Environmental Role of Nitrogen-fixing Blue Green Algae and Asymbiotic Bacteria, Uppsala, Sweden; J. J. Tarrand and N. R. Krieg. 1977. Abstk. Annu. Meet. Am. Soc. Microbiol. p. 159; M. E. Tyler and J. R. Milam. 1977. Abst. Annu. Meet. Am. Soc. Microbiol. p. 160; M. E. Tyler, J. R. Milam, and D. A. Zuberer. 1977. International Symposium on Limitations and Potentials of Biological Nitrogen Fixation in the Tropics. Summary of papers. Univ. of Brasilia, Brazil. p. 77).

As indicated by Krieg and Hylemon (1976), the taxonomic status of $S$. lipoferum has been uncertain. Therefore, the objectives of the present report were: (i) to determine by the use of deoxyribonucleic acid (DNA) base composition, and especially by DNA homology experiments, how many species are represented by the various strains of the $S$. lipoferum group; (ii) to learn which phenotypic characteristics can, by correlation with the genetic data, serve to distinguish such species; (iii) to provide a general characterization of the organisms; and (iv) to investigate the problem of which genus would be the most appropriate for the organisms.

\section{Methods and Materials}

Strains Used

The various strains studied are listed in Table 1. Upon receipt, each strain was checked for purity by streaking twice on modified peptone - succinate salts (MPSS) agar (Caraway and Krieg 1974). Stock cultures were maintained in the $\mathrm{N}$-free semisolid malate medium of Day and Döbereiner (1976) containing $0.005 \%$ yeast extract. Strains requiring yeast extract were transferred biweekly; the remainder were transferred monthly. All stock cultures were grown at $30^{\circ} \mathrm{C}$. The strains were also preserved toward the end of the study by suspending the cells in nutrient broth containing $10 \%$ dimethyl sulfoxide and freezing in liquid nitrogen.

\section{Morphology}

Cell dimensions were determined from photomicrographs taken by phase-contrast microscopy. The nagnification was accurately determined from similar photographs of a stage micrometer. The type of fagellation was determined by electron microscopy using preparations shadowed with tungsten oxide.

\section{Acidification of Sugar Media}

A medium of the following composition was used $(\mathrm{g} / \ell)$ : yeast extract (Difco), 0.05; $\mathrm{K}_{2} \mathrm{HPO}_{4}, 0.25: \mathrm{FeSO}_{4} \cdot 7 \mathrm{H}_{2} \mathrm{O}, 0.01$; $\mathrm{Na}_{2} \mathrm{MoO}_{4} \cdot 2 \mathrm{H}_{2} \mathrm{O}, 0.001 ; \mathrm{MnSO}_{4} \cdot \mathrm{H}_{2} \mathrm{O}, 0.002 ; \mathrm{MgSO}_{4} \cdot 7 \mathrm{H}_{2} \mathrm{O}, 0.2$; $\mathrm{NaCl}, 0.1 ; \mathrm{CaCl}_{2} \cdot 2 \mathrm{H}_{2} \mathrm{O}, 0.026 ;\left(\mathrm{NH}_{4}\right)_{2} \mathrm{SO}_{4}, 1.0$; biotin, 0.0001; brom thymol blue (aqueous), 0.0375; agar (Difco), 15.0. The $\mathrm{pH}$ was adjusted to 7.1 with $\mathrm{KOH}$. Each sugar was sterilized by filtration and added aseptically to the sterile basal medium to give a final concentration of $1.0 \%$ The sugar media were then added to sterile microtiter plates (flat-bottomed wells. NUNC), about $0.16 \mathrm{ml}$ per well. All of the wells of a given plate contained the same kind of sugar. The method of Wilkins and Walker (1975) was used for filling and inoculating the wells, by use of a replicator constructed of a plastic block with projecting wire brads. The replicator was sterilized by alcohol and by subsequent exposure to an intense source of ultraviolet light; it was then inoculated from a master microtiter plate where each well contained a different strain $(0.16 \mathrm{ml}$ of a 48 -h-old MPSS broth culture). By pressing the replicator on to the master plate, each wire brad was inoculated, and the replicator was then pressed on to a microtiter plate containing the sugar medium. Thus, each brad would inoculate a particular strain into a particular well of sugar agar. The replicator was returned to the master plate before inoculating another plate of sugar medium. A number of wells located at various positions were not inoculated and served as controls for sterility of the medium and also to indicate that migration of cultures from one well to another did not occur. After inoculation, the plates were covered with sterile lids and incubated at $37^{\circ} \mathrm{C}$ for $72 \mathrm{~h}$. The $\mathrm{pH}$ of each well was then determined with a small $\mathrm{pH}$ electrode as described by Wilkins and Walker (1975). The $\mathrm{pH}$ of uninoculated wells ranged from 5.7 to 6.2 , presumably because of absorption of carbon dioxide. Acidification of the medium by a strain was considered positive if the $\mathrm{pH}$ of the well was 3.9-5.0. 
TARRAND ET AL.

TABLE 1. Origin of D. lipoferum strains

\begin{tabular}{|c|c|c|c|c|}
\hline Strain No. & Country & Place & Plant roots or soil & Isolated by: \\
\hline $\begin{array}{l}\text { Sp } 4 \\
S p 7\end{array}$ & Brazil & Rio de Janeiro & Digitaria & J. Döbereiner \\
\hline $\begin{array}{l}\text { Sp } 7 \\
\text { Sp } 13\end{array}$ & ", & $"$ & , & , \\
\hline Sp $13 v$ & $"$ & $"$ & $"$ & $"$ \\
\hline Sp 34 & $"$ & $"$ & ", & $"$ \\
\hline $\mathrm{Sp} 35$ & $"$ & $"$ & $"$ & " \\
\hline Sp $51 \mathrm{e}$ & " & $"$ & Wheat & ", \\
\hline Sp 52 & $"$ & $"$ & Sorghan & $"$ \\
\hline Sp T60 & $"$ & $"$ & Wheat & $"$ \\
\hline Sp 67 & $"$ & $"$ & Maize & $"$ \\
\hline Sp 75 & $"$ & $"$ & $"$ & $"$ \\
\hline Sp 80 & $"$ & ", & $"$ & $"$ \\
\hline Sp 81 & $"$ & $"$ & $"$ & $"$ \\
\hline Sp 82 & $"$ & $"$ & $"$ & $"$ \\
\hline Sp P1 & Peru & & Soil & $"$ \\
\hline $\mathrm{Sp} P 2$ & & & $"$ & " \\
\hline Sp F4 & U.S.A. & Gainesville & Millet & S. H. Schank \\
\hline $\begin{array}{l}\text { Sp F6 } \\
\text { Sp Br } 8\end{array}$ & Brazil & Brasilia & Soil & " Döhereinar. \\
\hline $\mathrm{Sp} \mathrm{Br} 11$ & DIaZil & $\begin{array}{l}\text { Brasilia } \\
\text { " }\end{array}$ & $\begin{array}{l}\text { Sonl } \\
\text { Maize }\end{array}$ & $\begin{array}{c}\text { J. Dobereiner } \\
\text { " }\end{array}$ \\
\hline Sp Br 13 & $"$ & "' & Soil & " \\
\hline Sp Br 14 & $"$ & $"$ & Wheat & $"$ \\
\hline Sp Br 21 & $"$ & $"$ & " & $"$ \\
\hline $\mathrm{Sp} \mathrm{A2}$ & Nigeria & Ibadan & Maize & $"$ \\
\hline Sp A7 & ". & $"$ & Rice & $"$ \\
\hline Sp A 8 & $"$ & $"$ & Panicum & " \\
\hline Sp MT 20 & Brazil & Mato Grosso & Soil & $"$ \\
\hline Sp MT 21 & $"$ & 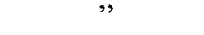 & $"$ & $"$ \\
\hline Sp L69 & " & Londrina & Wheat & $"$ \\
\hline $\mathrm{Sp} \mathrm{Col} \mathrm{lc}$ & Colombia & & Soil & $"$ \\
\hline Sp RG 8a & Brazil & Passo Fundo & Wheat & J. Döbereiner \\
\hline Sp RG 16a & $"$ & , & Lolium & $"$ \\
\hline Sp RG $20 b$ & $"$ & $"$ & Wheat & $"$ \\
\hline JM 6А2 & Ecuador & & Maize & J. R. Milam \\
\hline JM 6B2 & $"$ & & $"$ & $"$ \\
\hline JM 24B4 & $"$ & & Musa sp. & $"$ \\
\hline JM 28A2 & " & & Panicum naxinum & $"$ \\
\hline JM 52B1 & Venezuela & & $\begin{array}{c}\text { Panicum maximuml } \\
\text { Maize }\end{array}$ & $"$ \\
\hline $\begin{array}{l}\mathrm{JM} 73 \mathrm{~B} 3 \\
\mathrm{JM} 73 \mathrm{C} 2 \mathrm{~B}\end{array}$ & $"$ & & Mralze & $"$ \\
\hline $\begin{array}{l}\text { JM } 73 \mathrm{C} 2 \mathrm{~B} \\
\mathrm{JM} 73 \mathrm{C} 3\end{array}$ & $"$ & & $"$ & $"$ \\
\hline $\mathrm{JM} 75 \mathrm{Al}$ & $"$ & & Panicum maximum & $"$ \\
\hline JM $82 A 1$ & $"$ & & Maize & $"$ \\
\hline JM 119A4 & U.S.A. & Gainesville & Millet & $"$ \\
\hline JM 125A2 & " & " & $"$ & $"$ \\
\hline $\mathrm{Cd}$ & $"$ & Riverside & Cynodon dactylon & D. L. Eskew \\
\hline Sp $59 b$ & Brazil & Rio de Janeiro & Wheat & J. Döbereiner \\
\hline Sp USA $5 b$ & U.S.A. & Pullman & Soil & $"$ \\
\hline Sp RG $6 x x$ & Brazil & Passo Fundo & Wheat & $"$ \\
\hline Sp RG 8c & $"$ & $"$ & "' & $"$ \\
\hline Sp RG 9c & $"$ & $"$ & $"$ & $"$ \\
\hline Sp RG $18 b$ & $"$ & $"$ & $"$ & $"$ \\
\hline Sp RG 19a & $"$ & $"$ & Digitaria & $"$ \\
\hline Sp RG 20a & $"$ & " & Wheat & $"$ \\
\hline $\mathrm{Sp} \mathrm{Col} \mathrm{2b}$ & Columbia & Papayan & Maize & $"$ \\
\hline Sp Col 3 & $"$ & " & Brachiaria & $"$ \\
\hline Sp Col 5 & $"$ & $"$ & Hyparhenia rufa & $"$ \\
\hline Sp Br 10 & Brazil & Brasilia & Soil & $"$ \\
\hline Sp Br 17 &,$"$ & $"$ & Maize & $"$ \\
\hline Sp A3a & Senegal & Dakar & Grass & $"$ \\
\hline Sp S1a & Sweden & Uppsala & Grass & $"$ \\
\hline
\end{tabular}


Acidification of glucose media was also determined by a tube method using liquid microtiter plate medium, liquid microtiter plate medium with $\mathrm{K}_{2} \mathrm{HPO}_{4}$ increased to $0.5 \mathrm{~g} / \ell$, and also a peptone-based medium having the following composition $(\mathrm{g} / \ell)$ : peptone (Difco), 2.0; $\left(\mathrm{NH}_{4}\right)_{2} \mathrm{SO}_{4}, 1.0 ; \mathrm{MgSO}_{4} \cdot 7 \mathrm{H}_{2} \mathrm{O}, 1.0 ;$ glucose (sterilized by filtration), $10.0 ; \mathrm{FeCl}_{3} \cdot 6 \mathrm{H}_{2} \mathrm{O}, 0.002$ $\mathrm{MnSO}_{4} \cdot \mathrm{H}_{2} \mathrm{O}, 0.002$; and brom thymol blue (aqueous), 0.025 The $\mathrm{pH}$ was adjusted to 7.1 with $\mathrm{KOH}$. The ability to ferment glucose or fructose was tested anaerobically by placing tubes of peptone-based broth or microtiter plate broth in jars containing Gas-Pak catalyst (Bioquest); the jars were then evacuated and refilled once with nitrogen and three times with hydrogen. The jars were incubated at $37^{\circ} \mathrm{C}$ for 2 weeks. The ability to grow with glucose under anaerobic conditions was also tested by the use of streaked plates of solid media.

\section{Requirement for biotin}

Preliminary evidence by an auxanographic method indicated that certain strains required biotin for growth. Subsequently, the following procedure was developed for distinguishing these strains. The medium used had the following composition $(\mathrm{g} / \ell)$ : $\mathrm{K}_{2} \mathrm{HPO}_{4}, 0.5$; succinic acid (free acid), $5.0 ; \mathrm{FeSO}_{4} \cdot 7 \mathrm{H}_{2} \mathrm{O}, 0.01$ $\mathrm{Na}_{2} \mathrm{MoO}_{4} \cdot 2 \mathrm{H}_{2} \mathrm{O}, \quad 0.002 ; \quad \mathrm{MgSO}_{4} \cdot 7 \mathrm{H}_{2} \mathrm{O}, 0.2 ; \mathrm{NaCl}, 0.1 ;$ $\mathrm{CaCl}_{2} \cdot 2 \mathrm{H}_{2} \mathrm{O}, 0.026 ;\left(\mathrm{NH}_{4}\right)_{2} \mathrm{SO}_{4}, 1.0$. The $\mathrm{pH}$ was adjusted to 7.0 with $\mathrm{KOH}$. Media with and without biotin $(0.0001 \mathrm{~g} / \ell)$ were prepared. Cultures grown in MPSS broth were inoculated into $25 \mathrm{ml}$ of $\frac{1}{4} \times$ nutrient broth (Difco) and incubated at $37^{\circ} \mathrm{C}$ for $48 \mathrm{~h}$. The cells were harvested by centrifugation, washed twice in $10 \mathrm{ml}$ of sterile distilled water, and suspended in water to a turbidity of 20 Klett units (blue filter, 16-mm cuvettes). Onetenth millilitre of this suspension was used to inoculate each 5 -ml volume of medium. Incubation was for $48 \mathrm{~h}$ at $37^{\circ} \mathrm{C}$. In cases where slight growth occurred in the medium lacking biotin, compared with much heavier growth in the medium with biotin. a second serial transfer $(0.1 \mathrm{ml})$ was made to media with and without biotin to confirm the requirement.

\section{Other Physiological Tests}

Physiological tests were performed as described by Hylemcn et al. (1973) except as indicated below. Tests for nitrate reduction and denitrification were performed as described by Neyrat $e t$ al. (1977). For the indol test, cells were cultured for $48 \mathrm{~h}$ in $1.0 \%$ tryp tone broth (Difco) containing $0.1 \%$ tryptophan; Escherichia coli was used as a positive control. The ability to use glucose as a sole carbon source for growth in $\mathrm{N}$-free medium was tested by using the $\mathrm{N}$-free semisolid medium of Day and Döbereiner (1976) with the following modifications: brom thymol blue was omitted, malate was replaced by $1 \%$ glucose (sterilized by filtration), and $0.00001 \%$ biotin was added. The medium was inoculated directly from cultures grown in semisolid malate medium and the growth response at $37^{\circ} \mathrm{C}$ was observed in 3 days. The following procedure was also used. Cultures grown for $48 \mathrm{~h}$ in $25 \mathrm{ml}$ of $\frac{1}{4} \times$ nutrient broth were harvested by centrifugation and suspended in $10 \mathrm{ml}$ of sterile water; $0.05 \mathrm{ml}$ of this suspension was added to the surface of each tube of medium. The medium used was as described above but also contained brom thymo blue (aqueous). The growth response was observed for 2 weeks.

For qualitative determination of sole carbon sources used, a modification of the defined medium described by Hylemon $t a t$. (1973) was used. The level of $\mathrm{K}_{2} \mathrm{HPO}_{4}$ was increased to $0.2 \%$; $0.00001 \%$ biotin and $1.5 \%$ purified agar (Difco) were added. Before adding the $\mathrm{CaCO}_{3}$ and biotin, the medium was acidified to $\mathrm{pH} 2.5$ with $\mathrm{HCl}$ to dissolve precipitates. It was then adjusted to $\mathrm{pH} 7.0$ with $\mathrm{KOH}$. Cells were prepared as for determination of the biotin requirement, except that the final suspension was adjusted to 30 Klett units instead of 20 . Two millilitres of suspension were used to seed $20 \mathrm{ml}$ of molten medium $\left(45^{\circ} \mathrm{C}\right)$ in a Petri dish. After solidification of the medium, sterile $7-\mathrm{mm}$ discs punched from Beckman electrophoresis filter paper (Cat. No.
319328) were dipped into $5 \%$ solutions of carbon sources sterilized by filtration. (Solutions of organic acids were adjusted to $\mathrm{pH} 7$ with $\mathrm{KOH}$ before use.) The paper discs were then placed near the periphery of the seeded agar plates (three discs per plate). The plates were incubated at $37^{\circ} \mathrm{C}$ for $72 \mathrm{~h}$. Any visible zone of turbidity around the dises, as judged with the naked eye by holding the plates against a dark background near a light source, constituted a positive growth response.

\section{DNA Base Composition}

DNA used for determination of base composition was prepared as previously described (Hylemon et al. 1973). A final concentration of $50 \mu \mathrm{g} / \mathrm{ml}$ was made in $0.025 M$ sodium phosphate buffer ( $\mathrm{pH} 6.8$ ) containing $0.01 \%$ sodium dodecyl sulfate. The preparations were dialyzed in this buffer together with the DNA from $E$. coli $\mathrm{B}$. Melting point $(\mathrm{T} \mathrm{m})$ values were determined using a Gilford thermospectrophotome ter containing a temperature sensor in the cuvette. The Tm value for $E$. coli $\mathrm{B}$ was normalized to $90.5^{\circ} \mathrm{C}$, and the $T \mathrm{~m}$ values of the test strains were increased by the same factor to give Tm values for $1 \times$ SSC. The moles \% guanine + cytosine $(\mathrm{mol} \% \mathrm{G}+\mathrm{C})$ values were calculted by the formula of Marmur and Doty (1962).

\section{DNA Homology Experiments}

For some initial DNA homology experiments, the DNA used for binding to membrane filters was prepared by the method of Marmur and Doty (1962); for most experiments, however, the DNA was prepared by the hydroxylapatite (HA) method of Johnson (1978). Comparative DNA homology experiments using both types of preparations indicated that it made little difference which of the two types of DNA was used for binding to filters. Thermal denaturation and binding to filters were done as described by Johnson and Cummins (1972). Filters with bound DNA were incubated before use in the following mixture at $73^{\circ} \mathrm{C}$ for $30 \mathrm{~min}$ to prevent non-specific binding of competitor DNA or radioactive homologous DNA: bovine serum albumin (fraction V), $0.03 \%$; polyvinyl pyrrolidone, 0.02\%; Ficol (Pharmacia Fine Chemicals, Uppsala, Sweden), $0.02 \%$

Competitor DNA was prepared by the HA method and was subjected to brief sonic oscillation before denaturation. The DNA was adjusted to $3 \mathrm{mg} / \mathrm{ml}$ in $0.001 M$ HEPES buffer $(N-2-$ hydroxyethyl-piperazine- $N^{\prime}$-(2-ethane)sulfonic acid) containing $0.02 M \mathrm{NaCl}$. NaOH was added to a concentration of $0.25 \mathrm{M}$ and the solution was incubated at $45^{\circ} \mathrm{C}$ for $15 \mathrm{~min}$ to allow denaturation of the DNA and also hydrolysis of any residual ribonucleic acid (RNA). The solution was quickly cooled in an ethanol-ice bath and neutralized with an equivalent amount of $\mathrm{HCl}$. The DNA was dialyzed against $2.2 \times \mathrm{SSC}(1 \times \mathrm{SSC}=$ $\mathrm{NaCl}, 0.15 M$; sodium citrate, $0.15 M ; \mathrm{pH}=7.0$ ) and adjusted to a final concentration of $1.5 \mathrm{mg} / \mathrm{ml}$ with $2.2 \times \mathrm{SSC}$.

For preparation of radioactive homologous DNA, cultures were grown with ${ }^{32} \mathrm{P}$ or ${ }^{33} \mathrm{P}$ (as orthophosphate). The use of isotopes of phosphorus was necessitated by the failure of strain Sp 7 to incorporate sufficient radioactivity into its DNA when supplied with various tritiated precursors of DNA synthesis (thymine, thymidine, adenine, and deoxyadenosine). The DNA was extracted by the HA method, dialy zed against $0.1 \times \mathrm{SSC}$, and denatured by heating at $100^{\circ} \mathrm{C}$ for $20 \mathrm{~min}$.

DNA homology experiments were performed as described by Johnson and Cummins (1972). All incubations were performed at $25^{\circ} \mathrm{C}$ below the $\mathrm{Tm}$ of the DNA, i.e., at $73^{\circ} \mathrm{C}$.

\section{Results}

DNA Base Composition

If significant differences were to occur in DNA base composition among a number of strains, this alone would be strong evidence for the existence of 
TABLE 2. Melting points ( $\mathrm{Tm}$ values) and $\mathrm{mol} \%$ $\mathrm{G}+\mathrm{C}$ values for the DNA of 11 strains of the S. lipoferum group

\begin{tabular}{|c|c|c|}
\hline Strain & $\begin{array}{l}\text { Average } \\
\text { Tm, }{ }^{\circ} \mathrm{C}^{a}\end{array}$ & $\begin{array}{c}\mathrm{Mol} \% \mathrm{G}+\mathrm{C} \\
( \pm 1 \%)\end{array}$ \\
\hline Sp 7 & 98.1 & 70 \\
\hline Sp 13 & 98.0 & 70 \\
\hline Sp 4 & 97.8 & 70 \\
\hline Sp 35 & 98.2 & 70 \\
\hline Sp 82 & 98.4 & 71 \\
\hline Sp 75 & 98.2 & 70 \\
\hline Sp $51 \mathrm{e}$ & 98.2 & 70 \\
\hline Sp T60 & 98.4 & 71 \\
\hline Sp $59 b$ & 97.9 & 70 \\
\hline Sp RGxx & 97.8 & 70 \\
\hline Sp USA 5b & $97.6,97.8^{b}$ & $69,70^{\circ}$ \\
\hline
\end{tabular}

more than one species. However, as indicated in Table 2, the mol $\% \mathrm{G}+\mathrm{C}$ values for 11 strains isolated from different regions and different plants were all very close to $70 \%$. This similarity indicated that the strains could possibly, but not necessarily, all belong to a single species.

\section{DNA Homology Experiments}

The results of the DNA homology experiments are presented in Table 3 . It can be seen that when strain Sp 7 was used as the reference strain, the other strains fell into two distinct but related groups: group I contains the strains with homology values of about $70 \%$ or higher, and group II contains the strains with homology values in the $30-50 \%$ range. In the reciprocal situation where Sp $59 \mathrm{~b}$ was used as the reference, those strains (group II) which had exhibited low homology with $\mathrm{Sp} 7$ now were found to have high homology with Sp $59 \mathrm{~b}$; conversely, those strains (group I) which had exhibited high homology with $\mathrm{Sp} 7$ were now found to have low homology with $\mathrm{Sp} 59 \mathrm{~b}$.

DNA homology values for strains of various bacterial genera were also determined, using Sp 7 and $S p 59 \mathrm{~b}$ as references. The bacterial strains used were chosen because they had mol \% $\mathrm{G}+\mathrm{C}$ values and (or) other characteristics similar to those of $S$. lipoferum. As indicated in Table 4, no DNA homology values higher than about $20 \%$ were obtained for these strains.

\section{Characteristics Correlated with the Two Homology Groups}

Certain characteristics could be correlated with the two DNA homology groups of $S$. lipoferum (Table 5). Only group II strains exhibited a requirement for biotin. Only group II strains were able to grow in semisolid $\mathrm{N}$-free medium with glu-
TABLE 3. DNA homology values for strains of the S. lipoferum group

\begin{tabular}{|c|c|c|}
\hline \multirow[b]{2}{*}{ Strain } & \multicolumn{2}{|c|}{ DNA homology values, $\%$} \\
\hline & Ref. $=\mathrm{Sp} 7$ & Ref. $=$ Sp 59b \\
\hline Sp 7 & 100 & 34 \\
\hline Sp 4 & 102 & 38 \\
\hline Sp 13 & 94 & 32 \\
\hline Sp $13 v$ & 103 & 47 \\
\hline Sp 34 & 81 & 43 \\
\hline Sp 35 & 74 & 42 \\
\hline Sp 5le & 71 & 41 \\
\hline Sp 52 & 85 & 44 \\
\hline Sp T60 & 85 & 30 \\
\hline Sp 67 & 80 & 30 \\
\hline Sp 75 & 71 & 49 \\
\hline Sp 80 & 84 & 52 \\
\hline Sp 81 & 73 & 41 \\
\hline Sp 82 & 73 & 41 \\
\hline Sp Pl & 72 & 46 \\
\hline Sp P2 & 82 & 52 \\
\hline Sp F4 & 80 & 35 \\
\hline Sp F6 & 74 & 40 \\
\hline Sp Br 8 & 84 & 37 \\
\hline Sp Br 11 & 67 & 38 \\
\hline Sp Br 13 & 72 & 41 \\
\hline Sp Br 14 & 81 & 38 \\
\hline $\mathrm{Sp} \mathrm{Br} 21$ & 80 & $N^{a}$ \\
\hline Sp A2 & 92 & 50 \\
\hline Sp A7 & 96 & 33 \\
\hline $\mathrm{Sp} \mathrm{A} 8$ & 81 & 42 \\
\hline Sp MT 20 & 82 & 39 \\
\hline Sp MT 21 & 81 & 35 \\
\hline Lp L69 & 83 & 49 \\
\hline Sp Col lc & 80 & 34 \\
\hline Sp RG 8a & 104 & 37 \\
\hline Sp RG 16a & 77 & 35 \\
\hline Sp RG 20b & 73 & 32 \\
\hline JM 6 A2 & 78 & 49 \\
\hline $\mathrm{JM}$ 6B2 & 87 & 48 \\
\hline $\mathrm{JM} 24 \mathrm{~B} 4$ & 83 & 48 \\
\hline $\mathrm{JM} 28 \mathrm{~A} 2$ & 91 & 46 \\
\hline JM 52B1 & 86 & 40 \\
\hline JM 73B3 & 81 & 45 \\
\hline $\mathrm{JM} 73 \mathrm{C} 2 \mathrm{~B}$ & 83 & 49 \\
\hline JM 73C3 & 79 & 40 \\
\hline JM 75Al & 77 & 45 \\
\hline JM 82Al & 90 & 45 \\
\hline JM 119A4 & 91 & 47 \\
\hline JM $125 \mathrm{~A} 2$ & 88 & 52 \\
\hline $\mathrm{Cd}$ & 100 & 49 \\
\hline Sp 59b & 31 & 100 \\
\hline Sp USA $5 b$ & 36 & 70 \\
\hline Sp RG $6 x x$ & 36 & 73 \\
\hline Sp RG 8c & 34 & 72 \\
\hline Sp RG 9c & 35 & 73 \\
\hline Sp RG 18b & 39 & 73 \\
\hline Sp RG 19a & 28 & 72 \\
\hline Sp RG 20a & 37 & 76 \\
\hline Sp Col 2b & 43 & 72 \\
\hline Sp Col 3 & 34 & 76 \\
\hline Sp Col 5 & 46 & 73 \\
\hline Sp Br 10 & 38 & 74 \\
\hline $\mathrm{Sp} \mathrm{Br} 17$ & 30 & 73 \\
\hline Sp A3a & 29 & 70 \\
\hline Sp Sla & 34 & 73 \\
\hline
\end{tabular}

aND not done. 
TABLE 4. DNA homology values for bacteria of various genera, with S. lipoferum strains used as reference

\begin{tabular}{|c|c|c|c|}
\hline \multirow[b]{2}{*}{ Genus and species } & \multirow[b]{2}{*}{ ATCC No. } & \multicolumn{2}{|c|}{ DNA homology values, $\%$} \\
\hline & & Ref. $=\mathrm{Sp} 7$ & Ref. $=$ Sp $59 b$ \\
\hline Pseudomonas testosteroni & $11996^{a}$ & 4 & 0 \\
\hline P. acidovorans & $\begin{array}{l}15668^{a} \\
15667\end{array}$ & $\begin{array}{r}20 \\
1\end{array}$ & $\begin{array}{r}14 \\
1\end{array}$ \\
\hline Aquaspirillum metamorphum & $15280^{a}$ & 0 & 13 \\
\hline A. peregrinum ${ }^{b}$ & $15387^{a}$ & 22 & 11 \\
\hline \multirow[t]{3}{*}{ A. fasciculus ${ }^{b}$} & $27740^{a}$ & 16 & 11 \\
\hline & 29048 & 5 & $\mathrm{NT}^{\mathrm{c}}$ \\
\hline & 29049 & 11 & NT \\
\hline Comamonas terrigena & $8461^{a}$ & 0 & 1 \\
\hline \multirow[t]{2}{*}{ Derxia glmmmosab } & $15994^{a}$ & 2 & 0 \\
\hline & 15995 & 0 & 20 \\
\hline Azomonas insignis" & 12523 & 10 & 1 \\
\hline A. macrocytogenes & 12335 & 6 & 7 \\
\hline Rhodospirilhmm rubrumb" & $11170^{a}$ & 16 & 0 \\
\hline
\end{tabular}

cose as the carbon source. Only group II strains appeared to possess some fermentative ability, as first noted by Dr. Max E. Tyler and Dr. James R. Milam, Department of Microbiology and Cell Science, University of Florida, Gainesville, Florida (personal communication). We found group II strains to be capable of acidifying glucose or fructose media anaerobically, of forming a small amount of gas (less than 5\% of the volume of the gas vials), of exhibiting slight growth in sugar broth anaerobically, and of forming minute colonies on sugar plates anaerobically. Yet group II strains grew far better aerobically than anaerobically, and like group I should be considered to have mainly a respiratory type of metabolism.

In peptone-based glucose broth, only group II strains caused acidification, as indicated in a preliminary report (Krieg 1977). By the microtiter plate replicator method, only group II strains produced a pH of 4.5 or less with glucose; however, 2 of 46 group I strains produced a weakly acidic reaction. In liquid microtiter plate medium, 6 of 46 group I strains caused acidification as evidenced by a yellow color; when the level of $\mathrm{K}_{2} \mathrm{HPO}_{4}$ of this medium was increased to $0.5 \mathrm{~g} / \ell$, these group I strains produced only a yellow-green color in $48 \mathrm{~h}$, while all group II strains produced a deep yellow color. Consequently, it appeared that group I strains, if capable of oxidizing glucose, produced a weaker reaction. Such group I strains were incapable of causing acidification of glucose media under anaerobic conditions.

In stock cultures of four group II strains ( $\mathrm{Sp} \mathrm{Br}$ 17, Sp RG 9c, Sp RG 20a, and Sp Col 5) variants appeared after continued transfer; these variants were no longer capable of acidifying the peptonebased glucose broth. They could cause acidification of microtiter plate glucose broth, but when the level of phosphate was increased to $0.5 \mathrm{~g} / \ell$ the $y$ produced only a yellow-green color in $48 \mathrm{~h}$. Their ability to ferment glucose or fructose was also diminished. The variants still exhibited a requirement for biotin, could use glucose as a sole carbon source for growth in $\mathrm{N}$-free semisolid medium, and exhibited the characteristic morphology of group II strains when cultured in semisolid $\mathrm{N}$-free malate medium $+0.005 \%$ yeast extract (see below).

Concerning morphology, both groups I and II had a similar appearance when cultured for $24 \mathrm{~h}$ in MPSS broth, namely, short, plump, slightly curved motile rods averaging $1.0 \mu \mathrm{m}$ in diameter and having a length of $2.1-3.8 \mu \mathrm{m}$ (see Fig. 1 A, B, and C). Many cells had pointed ends, and PHB granules were visible. When a loopful from an MPSS broth culture was transferred to semisolid $\mathrm{N}$-free malate medium $+0.005 \%$ yeast extract, group Il strains tended to become wider $(1.4-1.7 \mu \mathrm{m})$, longer $(5 \mu \mathrm{m}$ to over $30 \mu \mathrm{m}$ ), and many S-shaped or helical cells appeared in $24-48 \mathrm{~h}$ (see Fig. $1 \mathrm{E}$ and F). Group II strains also tended to become non-motile or only sluggishly motile in the semisolid malate medium. The long cells seemed eventually to undergo fragmentation into shorter, ovoid cells; many of these later became large and pleomorphic and were filled with highly refractile granules, probably of PHB. Some of these large cells appeared to be compartmented. In contrast to group II strains, group I strains retained an appearance in semisolid malate medium similar to that in MPSS broth, remaining predominantly short and vibroid (see Fig. ID); after 
TABLE 5. Distinction between DNA homology groups on the basis of phenotypic characters

\begin{tabular}{|c|c|c|}
\hline \multirow[b]{2}{*}{ Test } & \multicolumn{2}{|c|}{$\%$ of strains positive } \\
\hline & $\begin{array}{l}\text { Homology } \\
\text { group I }\end{array}$ & $\begin{array}{l}\text { Homology } \\
\text { group II }\end{array}$ \\
\hline $\begin{array}{l}\text { Glucose used as sole carbon source } \\
\text { for growth in } \mathrm{N} \text {-free semisolid } \\
\text { medium }\end{array}$ & $0^{n}$ & 100 \\
\hline $\begin{array}{l}\text { Acidification of glucose media: } \\
\quad \text { Microtiter plate method; } 72 \mathrm{~h}\end{array}$ & $(\mathrm{pH} 5.2-5.8)$ & $\begin{array}{c}100 \\
(\mathrm{pH} \leqq 4.5)\end{array}$ \\
\hline $\begin{array}{l}\text { Peptone-based glucose broth, } 96 \mathrm{~h} \\
\text { Microtiter glucose broth; } 48 \mathrm{~h}\end{array}$ & $\begin{array}{c}0 \\
13^{c} \\
\text { (deep yellow) }\end{array}$ & $\begin{array}{c}100 \\
100 \\
\text { (deep yellow) }\end{array}$ \\
\hline $\begin{array}{l}\text { Microtiter glucose broth with } \\
2 \times \text { phosphate; } 48 \mathrm{~h}\end{array}$ & $\begin{array}{c}13^{c} \\
\text { (yellow-green) }\end{array}$ & $\begin{array}{c}100 \\
\text { (deep yellow) }\end{array}$ \\
\hline $\begin{array}{l}\text { Acidification of mannitol, ribose, and } \\
\text { sorbitol (microtiter plate method; } \\
72 \mathrm{~h} \text { ) }\end{array}$ & 0 & $80^{d}$ \\
\hline $\begin{array}{l}\text { Acid from glucose and fructose } \\
\text { anaerobically; slight growth also } \\
\text { occurs; } 2 \text { weeks }\end{array}$ & 0 & $87,+13 \%$ variable \\
\hline $\begin{array}{l}\text { 1n semisolid } \mathrm{N} \text {-free malate medium }+ \\
0.005 \% \text { yeast extract, cells become } \\
\text { wider, longer (often S-shaped or } \\
\text { helical), and nommotile; } 24-48 \mathrm{~h}\end{array}$ & 0 & 100 \\
\hline $\begin{array}{l}\text { Sole carbon sources (by paper disc } \\
\text { test: } 72 \text { h) } \\
\text { a-Ketoglutarate } \\
\text { Mannitol } \\
\text { Sorbitol } \\
\text { Ribose } \\
\text { Glucose }\end{array}$ & $\begin{array}{l}0 \\
0 \\
0 \\
0 \\
9^{i}\end{array}$ & $\begin{array}{c}100 \\
80,+7 \% \text { variable } \\
67,+13 \% \text { variable } \\
40,+27 \% \text { variable }^{t} \\
100\end{array}$ \\
\hline 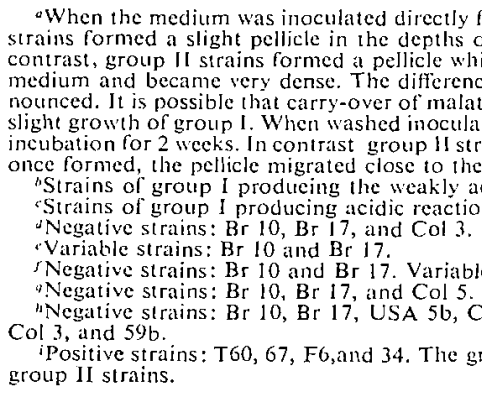 & 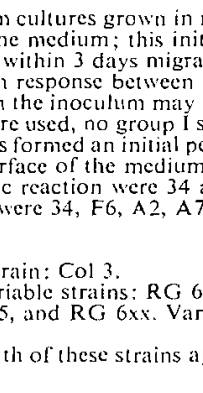 & 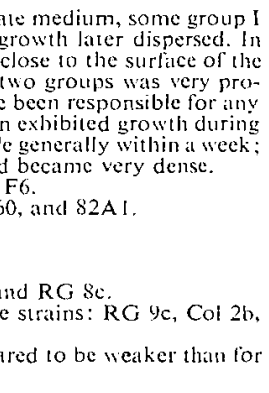 \\
\hline
\end{tabular}

several weeks, however, some S-shaped cells could be observed (see reference by Krieg 1976, Fig. 2) as well as some large, pleomorphic, granule-filled forms. Similar pleomorphic forms were also observed under washout conditions in chemostat cultures. In batch cultures group I strains retained their motility for a month or longer.

\section{Other Characteristics of the Strains}

Additional characteristics of the strains of both homology groups are summarized in Table 6. One of the most interesting characteristics concerned the type of flagellation. When cultured in MPSS broth at either 30 or $37^{\circ} \mathrm{C}$, the cells exhibited a single polar flagellum. When cultured on MPSS agar at $30^{\circ} \mathrm{C}$, however, the cells exhibited numerous lateral flagella in addition to the polar flagellum. The lateral flagella possessed a shorter wavelength than the polar flagellum and they also appeared to be thinner, as judged from the shadowed preparations (see Fig. 2). Although some lateral flagella were also observed on cells cultured on agar at $37^{\circ} \mathrm{C}$, the lower temperature appeared to be much more favorable for their formation. The occurrence 

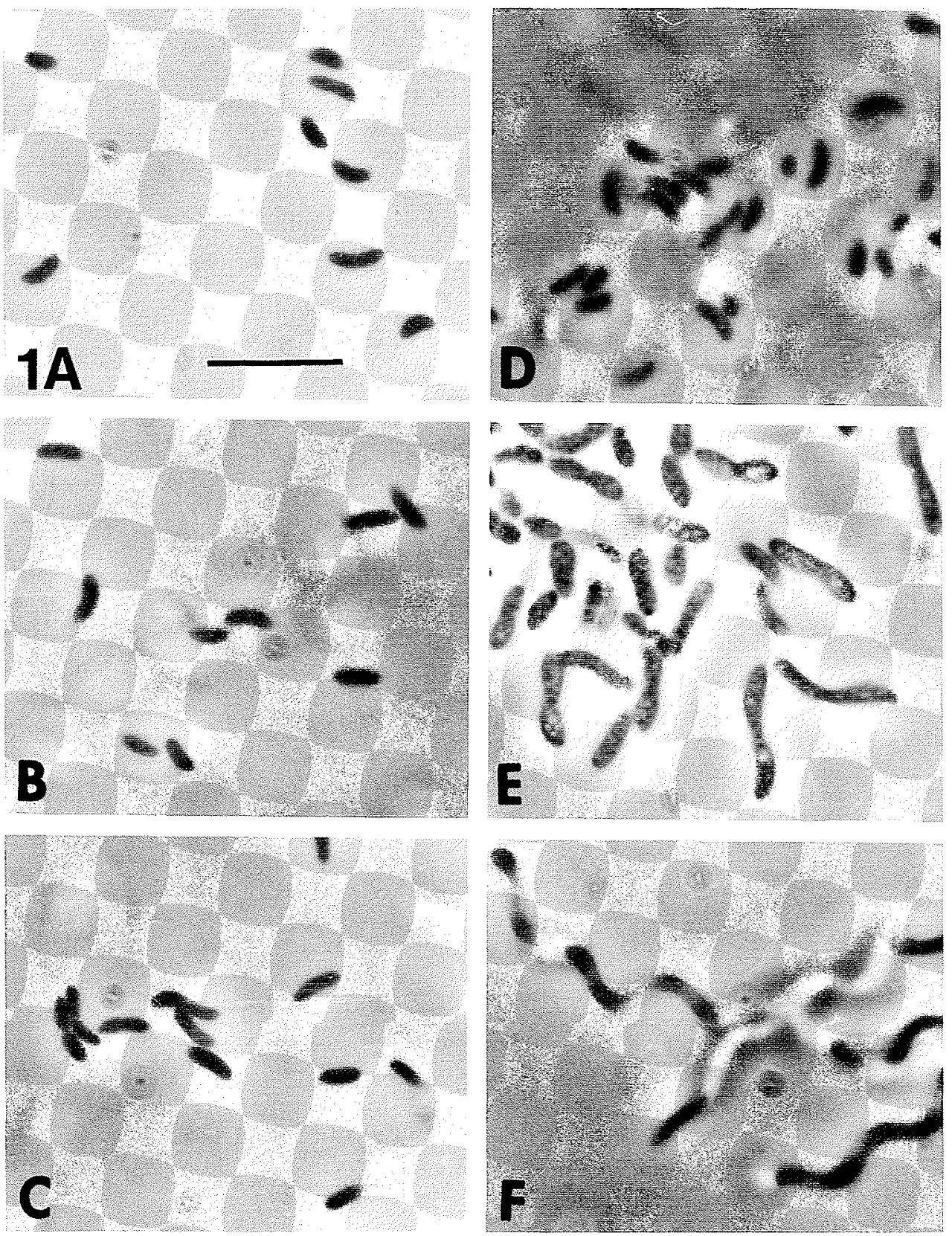

FIG. 1. Appearance of strains of S. lipoferum by phase-contrast microscopy. A-C: strains Sp 7, Sp 59b, and Sp RG 20a, respectively, cultured in MPSS broth at $37^{\circ} \mathrm{C}$ for $24 \mathrm{~h}$. D and E: strains SP 7 and Sp 59b, respectively, cultured in semisolid nitrogen-free malate medium $+0.005 \%$ yeast extract for $48 \mathrm{~h} ; \mathrm{E}=$ strain Sp RG 20 a cultured similarly but for only $24 \mathrm{~h}$. The bar $=10 \mu \mathrm{m}$.

of lateral flagella appeared to be similar to the situation described for Pseudomonas stutzeri (Doudoroff and Palleroni 1974), Vibrio parahaemolyticus (Shinoda and Okamoto 1977), and Vibrio alginolyticus (Boer et al. 1975).

As already noted by Okon et al. (1976a), potato or nutrient agar colonies of $S$. lipoferum tend to develop a light pink pigment. However, certain strains formed very deep pink colonies on MPSS agar: Sp 13v, Sp RG 8a, and Cd. Strains Sp 13v and Sp RG 8a were spontaneous mutants derived from ordinary light pink strains. Strain $\mathrm{Cd}$ was isolated 

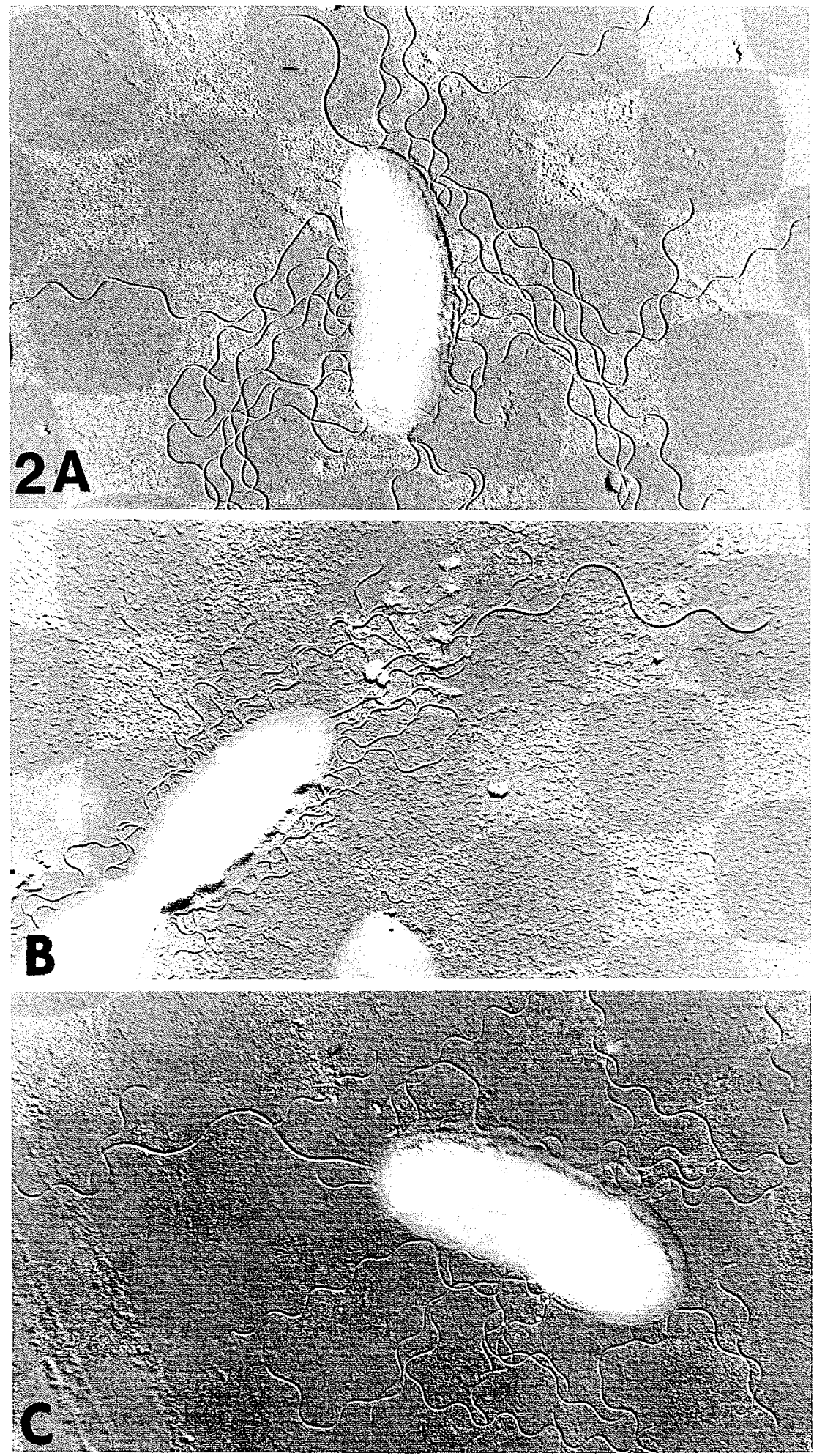

Fig. 2. Electron micrographs of (A) strain Sp 7, (B) strain Sp 59b, and (C) strain BR 17 cultured on MPSS agar at $30^{\circ} \mathrm{C}$. Both the single polar flagellum and also numerous lateral fiagella of shorter wavelength can be seen. $14000 \times$. 
TABLE 6. Additional physiological characteristics of DNA homology groups I and II

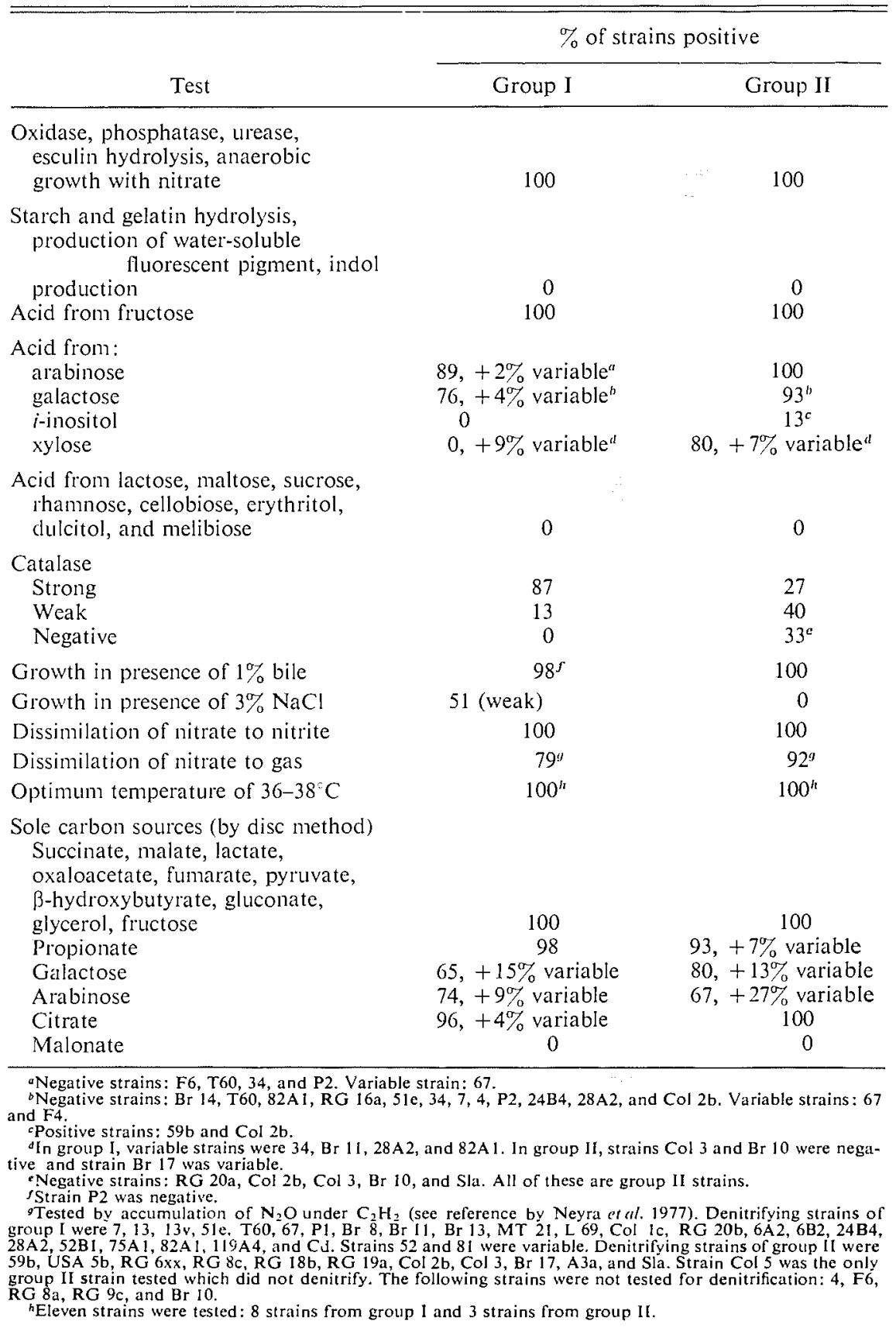

as a deep pink strain from Cynodon dactylon roots by Eskew et al. (1977). The three deep pink strains all exhibited nearly $100 \%$ homology with the reference strain $\mathrm{Sp} \mathrm{7,} \mathrm{in} \mathrm{which} \mathrm{no} \mathrm{such} \mathrm{deep} \mathrm{pink} \mathrm{col-}$ onies have yet been found. Studies of strain Cd by Eskew et al. (1977) indicate that the pigment is probably a $b$-or $c$-type cytochrome.

\section{Discussion}

Studies by Johnson (1973) have indicated that in the DNA homology range of $80-100 \%$ the major variations that are being measured are differences in genome size and alterations in the linear arrangements of cistrons, whereas in the homology range of $30-50 \%$ differences in the base sequences 
of the cistrons become increasingly important. DNA homology values of $70 \%$ have been considered to represent a sufficient degree of genetic relationship as to warrant consideration of the strains as belonging to a single species (Brenner 1973; Johnson 1973). Consequently, we believe that the results of our DNA homology experiments with $S$. lipofermm strains indicate that two distinct but related species exist, and also that the species belong together within the same genus.

Within group I a continuum of homology values exists from about 70 to $100 \%$, with Sp 7 as the reference strain. In contrast, none of the group II strains exhibited more than $76 \%$ homology to the

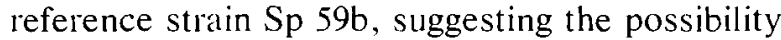
that group II might consist of two subspecies-one containing Sp 59b, and the other containing the remaining strains. However, whether the latter strains exhibit high homology with each other has not been determined. On the basis of phenotypic characteristics, so far there appears to be no correlation of any particular characteristics with lower or higher homology values within either group II or group I.

Considerations of the Generic Status of the Strains

On the basis of their vibroid and sometimes helical shape, and also their preference for the salts of organic acids as carbon source, $S$. lipoferum was originally assigned to the genus Spirillum Ehrenberg by Beijerinck (1925). However, this genus is presently restricted to very large microaerophilic, helical organisms having bipolar tufts of flagella and whose mol \% $\mathrm{G}+\mathrm{C}$ is about 38 (i.e., organisms resembling Spirillam volutans) (Hylemon et al. 1973). Consequently, the genus Spirillum is not appropriate for $S$. lipoferum strains.

If significant DNA homology were to occur between $S$. lipoferum and an established member of a particular genus, this would provide a firm basis for assigning $S$. lipoferum to that genus. As indicated in Table 4, however, none of a number of strains from varous genera having certain similarities to $S$. lipoferum were found to exhibit homology values higher than about $20 \%$, when strains $\mathrm{Sp} 7$ and $\mathrm{Sp}$ $59 b$ were the reference strains. Such values are not considered to be significant (Johnson 1973). DNA homology studies are in fact most useful at the species level rather than the genus level of taxonomy, and lack of significant DNA homology would not preclude assignment of an organism to a particular genus. It is likely that ribosomal ribonucleic acid - DNA (rRNA-DNA) studies would be useful at the genus level, since they indicate broader relationships between strains than are evident from DNA-DNA studies (Johnson and Francis 1975; Palleroni et al. 1973). In the absence of such studies, however, assignment of S. lipoferum strains to an appropriate genus must presently be done on the basis of phenotypic characteristics.

Among the known aerobic nitrogen-fixing bacteria Derxia gummosa seems to resemble $S$. lipoferum most closely. It has a mol $\% \mathrm{G}+\mathrm{C}$ of 70 , has a cell diameter similar to that for $S$. lipoferum, possesses PHB granules, and has been isolated from tropical soils (Becking 1974b). However, Derxia is a straight rod, is incapable of reducing nitrate even to nitrite, and does not grow on malate or succinate. It forms a gummy slime or capsule and possesses only a single polar flagellum. For these reasons we believe that $S$. lipoferum should not be assigned to this genus.

Because of the curvature of the cells and also the formation of S-shaped or even spirillum-shaped cells under certain conditions, $S$. lipoferum might resemble members of the genus Aquaspirillum (Hylemon et al. 1973). However, S. lipoferum would be atypical for this genus because it has (i) a higher mol \% $\mathrm{G}+\mathrm{C}$ value (70\% compared to $50-65 \%$ ); (ii) a generally vibroid shape rather than a helical shape; (iii) an ability to grow anaerobically with nitrate and to denitrify; (iv) only a single polar flagellum when grown in broth or lateral flagella when grown on agar; $(v)$ an ability to oxidize a number of carbohydrates; (vi) some fermentative ability (by group II); (vii) a vitamin requirement (by group II); (viii) lack of catalase activity (by some strains of group II); (ix) nitrogenase activity; and (x) an association with plant roots. Although some species of Aquaspirillum are not typical of the genus in certain respects (Krieg 1976), the combination of atypical characteristics given above would seem to provide a firm basis for excluding $S$. lipoferum from the genus Aquaspirillum.

On the basis of DNA base composition, $S$. lipoferum would be excluded from the nitrogenfixing genera Azomonas and Beijerinckia (Becking $1974 a$; Johnstone $1974 b$ ). The genus $A$ zobacter has a mol \% $\mathrm{G}+\mathrm{C}$ of 63-66, however, and one of the species ( $A$. paspali) is associated with root surfaces (Johnstone 1974a). Yet Azotobacter species have respiratory protection for nitrogenase, whereas $S$. lipoferum lacks such protection. Moreover, Azotobacter species are large and ovoid in shape, have only peritrichous flagella, and form thickwalled cysts (Johnstone 1974a). The genus Rhizobium is far more highly specialized for sym- 
biotic nitrogen fixation than is $S$. lipoferum. Therefore, both Azotobacter and Rhizobium would seem to be inappropriate genera for $S$. lipofer $\mathrm{llm}$.

On the basis of purely phenotypic characteristics, such as vibrioid shape, ability to reduce nitrate, the occurrence of lateral flagella in addition to a single polar flagellum, and ability to ferment as well as to oxidize sugars, the genus Vibrio (Shewan and Véron 1974) might seem to be the most suitable for S. lipoferum. However, the $\mathrm{mol} \% \mathrm{G}+\mathrm{C}$ for the genus Vibrio (40-50\%) is far too low to permit inclusion of $S$. lipoferum. Certain oxidative, polar-flagellated, vibrioid bacteria have been assigned to the genus Comamonas (Davis and Park 1962), for which the type species is $C$. terrigena. This species is similar to certain members of the genus Pseudomonas, especially $P$. testosteroni (Hugh 1965). Comamonas terrigena has a mol \% G + C of 64 (Sebold and Véron 1963) and is incapable of catabolizing any sugar. Consequently, it would appear that this genus would not be appropriate for S. lipoferum.

Members of the genus Pseudomonas resemble $S$. lipoferum in certain respects. For example, $P$. stut zeri has a type of flagellation similar to that of $S$. lipoferum and can also denitrify (Doudoroff and Patleroni 1974). The mol \% $\mathrm{G}+\mathrm{C}$ for the genus is $58-70$, and vibrioid organisms are not excluded by the definition of the genus (Doudoroff and Palleroni 1974). The occurrence of some fermentative ability in group II of $S$. lipoferum, however, would exclude $S$. lipoferum from the genus. Moreover, unlike plant-associated pseudomonads, S. lipoferum is certainly not pathogenic for plants; indeed, it is beneficial.

Some interesting similarities exist between $S$. lipoferum and the polar-flagellated organism Rhodospirillum rubrum. For example, $R$. rubrum requires biotin, can grow aerobically in the dark, has a vibrioid shape, and produces a pink pigment. The $\mathrm{mol} \% \mathrm{G}+\mathrm{C}$ for $R$. rubrum is 64-66 (Pfennig and Trüper 1974). One of the most interesting similarities is that like $R$. rubrum but unlike other nitrogen-fixing organisms, the Fe protein component of the nitrogenase complex of $S$. lipoferum is almost inactive upon isolation and must be activated by an activating factor that is interchangeable with the factor from R. rubrum (Burris et al. 1977). Unlike $S$. lipoferum, $R$. rubrum has bipolar tufts of flagella. Moreover, $R$. rubrum is photosynthetic whereas $S$. lipoferum does not appear to be photosynthetic. Strains Sp 7 and 59b were incapable of growing in deep, petrolatum-sealed tubes of peptone - succinate salts agar under illumination. Since all species of Rhodospirillum are capable of using succinate as an electron donor for photosynthesis (Pfennig and Trüper 1974), if the two strains of $S$. lipoferum had belonged to this genus they should have been able to grow under these conditions.

In our opinion, the best course to pursue with regard to the generic placement of $S$. lipofertum would be to assign the organisms to a new genus. We believe the name Azospirillum would be suitable for this genus for the following reasons: (i) The name Spirillum lipoferum, designated by Beijerinck in 1925, has become a familiar one since the work of Döbereiner and Day in 1974, and retention of the term "spirillum" in the new generic name would minimize confusion among those who are working with these organisms. (ii) Although mainly vibrioid, the organisms can exhibit Sshaped or helical cells under certain conditions. (iii) Certain spirilla, such as Aquaspirillum aquaticum, A. delicatum, A. metamorphum, and Oceanospirillum japonicum, generally have less than one helical turn, but are nonetheless included with other spirilla (Hylemon et al. 1973). (iv) Like spirilla, S. lipoferum strains have intracellular $\mathrm{PHB}$ granules, have mainly a respiratory type of metabolism, and seem to grow well on the salts of organic acids as carbon sources.

A description of the genus follows:

Azospirillum gen. Nov. (A· zo $\cdot \mathrm{spi} \cdot \mathrm{ril}$ ' lum. French noun azote, nitrogen; Greek noun spira, a spiral; spillum, a small spiral; Azospirillum, a small nitrogen spiral.) Cells generally vibrioid, but may be $\mathrm{S}$-shaped or helical in semisolid $\mathrm{N}$-free malate medium $+0.005 \%$ yeast extract. Cell diameter about $1 \mu \mathrm{m}$. Motile in liquid media by a single polar flagellum; on solid media at $30^{\circ} \mathrm{C}$ numerous lateral flagella are formed in addition to the single polar flagellum. Prominent intracellular granules of $\mathrm{PHB}$ are present. Slime not formed. Possess mainly a respiratory type of metabolism, but some fermentative ability may also be present. Under severe oxygen limitation nitrate is dissimilated to nitrite, nitrous oxide, or nitrogen gas. Molecular nitrogen is fixed under microaerophilic conditions. Oxidasepositive. Grow well on salts of organic acids such as malate, succinate, pyruvate, or lactate; certain carbohydrates may also serve as carbon sources. Optimum temperature, about $37^{\circ} \mathrm{C}$. Isolated from soils and from roots or various plants. The $\mathrm{mol} \% \mathrm{G}$ $+\mathrm{C}$ of the DNA is about 70 by thermal denaturation methods. The type species is Azospirillum lipoferum.

In the genus Azospirillum, two species would presently occur. Although Beijerinck's cultures are no longer extant, it seems likely that his organism 
belonged to group II. Beijerinck referred to the development of his spirilla in solutions of glucose or mannitol inoculated with soil, although the spirilla were later displaced by overgrow th with Azotobacter and Clostridium (Beijerinck 1925). When malate was used as the carbon source, no such displacement occurred. Moreover, Beijerinck (1925) provided drawings of cells cultured in sugar medium. Beijerinck's cells could also exhibit a helical shape. All of this strongly supports the idea that group II organisms were involved. Consequently, we believe that the name Azospirillum lipoferum should be applied to group II strains. For group I strains, we propose the name Azospirillum brasilense. Descriptions of the two species follow.

Azospirillum lipoferum (Beijerinck) comb. nov. (li . $\mathrm{po}^{\prime}$ fe- rum. Greek noun lipus, fat; Latin verb fero, to carry; Modern Latin adjective lipoferus, fatbearing). Capable of using glucose as a sole carbon source for growth in $\mathrm{N}$-free semisolid medium containing biotin. Capable of aerobic growth and acid production in peptone-based glucose medium. Media containing ribose, mannitol, or sorbitol are usually acidified. Acidification and scant growth usually occur in glucose or fructose media under anaerobic conditions. Biotin required for growth. In semisolid $\mathrm{N}$-free malate medium $+0.005 \%$ yeast extract, cells tend to become wider (about 1.4-1.7 $\mu \mathrm{m}$ ), longer (often S-shaped or helical), and non-motile. The neotype strain is Sp 59b (A TCC 29707). Reference strains Sp RG6xx, Sp Br 17, and Sp RG 20a have been deposited with the American Type Culture Collection (ATCC) under the numbers 29731, 29709, and 29708, respectively.

Azospirillum brasilense sp. nov. (bra. si. len' se. Pertaining to the country of Brazil, South America). Not capable of using glucose as a sole carbon source for growth in $\mathrm{N}$-free semisolid medium. No acidification of peptone-based glucose medium occurs; acidification of peptone-free media buffered with phosphate may occur, but the reaction is weaker than with A. lipoferum. Media containing ribose, mannitol, or sorbitol are not acidified. No fermentative ability for sugars is present. Vitamins are not required for growth. In semisolid $\mathrm{N}$-free malate medium $+0.005 \%$ yeast extract, cells tend to remain about $1.0 \mu \mathrm{m}$ in diameter, short, vibrioid, and motile; S-shaped cells may occur in old cultures. The type strain is Sp 7 (ATCC 29145). Reference strains Sp Cd and Sp 35 have been deposited with the ATCC under the numbers 29710 and 29711 , respectively.

\section{Acknowledgements}

We are grateful to Dr. John L. Johnson of the Anaerobe Laboratory, Virginia Polytechnic Institute and State University, Blacksburg, Virginia, for teaching us the DNA homology technique and for his help and encouragement. We are also grateful to Mr. Robert H. Lipsky and to Mrs. Connie Alexander for their valuable assistance. We thank Dr. Max E. Tyler, Department of Microbiology and Cell Science, University of Florida, and Dr. Yaacov Okon, Department of Biochemistry, University of Wisconsin, Madison, Wisconsin, for supplying many of the strains. The work was supported by the Rockefeller Foundation, Grants GA AGR 7523 and GA AS 7361.

BECKING, J. H. 1963. Fixation of molecular nitrogen by an aerobic Vibrio or Spirillum. Antonie van Leeuwenhoek: J. Microbiol. Serol. 29:326.

1974a. The genus Beijerinckia. In Bergey`s Manual of determinative bacteriology. 8th ed. Edited by R. E. Buchanan and N. E. Gibbons. The Williams and Wilkins Co., Baltimore, MD. pp. 256-260.

1974b. The genus Derxia. In Bergey's Manual of determinative bacteriology. 8th ed. Edited by R. E. Buchanan and N. E. Gibbons. The Williams and Wilkins Co., Baltimore. MD. pp. 260-261.

BEIJERINCK, M. W. 1922. Azotobacter chroococcum als indikator van de vruchtbartheid van den grond. K. Ned. Akad Wet. Versl. Gewone Vergad. Afd. Natuurkd. 30: 431-438. 1925. Über ein Spirillum, welches freien Stickstoff binden kann? Zentrabl. Bakteriol. Parasitenkd. Infektionskr. Hyg. Abt. 2, 63: 353-359.

Boer, W. E., C. Golten, and W. A. ShefFers. 1975. Effects of some chemical factors on fagellation and swarming of Vibrio alginolyticus. Antonie valn Leeuwenhoek; J. Microbiol. Serol. 41: 385-403.

BrenNer, D. J. 1973. Deoxyribonucleic acid reassociation in the taxonomy of enteric bacteria. Int. J. Syst. Bacteriol. 23: 298-307.

Burris, R. H.. Y. Okon, and S. L. Albrecht. 1977. Physiological studies of Spirillum lipoferlum. In Genetic engineering for nitrogen fixation. Edited by A. Hollaender. Plenum Press, New York. pp. 445-450.

CARAWAY, B. H., and N. R. KRIEg. 1974. Aerotaxis in Spirillum volutans. Can. J. Microbiol. 20: 1367-1377.

Davis, G. H. G. and R. W. A. Park. 1962. A taxonomic study of certain bacteria currently classified as Vibrio species. J. Gen. Microbiol. 27: 101-119.

DAY, J. M., and J. DöBEREINER. 1976. Physiological aspects of $\mathrm{N}_{2}$-fixation by a Spirillum from Digitaria roots. Soil Biol. Biochem. 8: 45-50.

De-Pollt, H., E. Matsui, J. Döbereiner, and E. Salati. 1977. Confirmation of nitrogen fixation in two tropical grasses by ${ }^{15} \mathrm{~N}_{2}$ incorporation. Soil Biol. Biochem. 9: 119-123.

DöBEREINER, J. 1977. Physiological aspects of $N_{2}$ fixation in grass-bacteria association. In Recent developments in nitrogen fixation. Edited by W. Newton, J. R. Postgate, and C. Rodriguez-Barrueco. Academic Press, London. pp. 513-522.

DÖBEREINER, J., and J. M. DAY. 1976. Associative symbioses in tropical grasses: characterization of microorganisms and dinitrogen fixing sites. In Symposium on nitrogen fixation. 
Edited by W. E. Newton and C. J, Nymans. Washington State Univ, Press, Pullman, WA. pp. 518-538.

DöBerEiner, J., I. E. MARRIEL, and M. NERY. 1976. Ecological distribution of Spirillum lipoferum Beijerinck. Can. J. Microbiol. 22: 1464-1473.

Doudoroff, M., and N. J. Palleroni. 1974. The genus Pseudomonas. In Bergey's Manual of determinative bacteriology. 8th ed. Edited by R. E. Buchanan and N. E. Gibbons. The Williams and Wilkins Co., Baltimore. pp. 217-243.

Eskew, D. L., D. D. Focht, and 1. P. TiNG. 1977. Nitrogen fixation, denitrification, and pleomorphic growth in a highly pigmented Spirillum lipoferum. Appl. Environ. Microbiol. 34: $582-585$.

Hugh, R. 1965. A comparison of Pseudomonas testosteroni and Comamonas terrigena. Int. Bull. Bacteriol. Nomencl. Taxon. 15: $125-132$.

Hylemon, P. B., J. S. Wells, JR., N. R. KRiEG, and H. W. JaNNASCH. 1973. The genus Spirillum: a taxonomic study. Int. J. Syst. Bacteriol. 23: 340-380.

Johnson, J. L. 1973. Use of nucleic acid homologies in the taxonomy of anaerobic bacteria. Int. J. Syst. Bacteriol. 23: $308-315$.

1978. Taxonomy of the Bacteroides. I. DNA homologies among Bacieroides fragilis and other saccharolytic Bacteroides species. Int. J. Syst. Bacteriol. 28: 245-256.

JoHnson, J. L., and C. S. Cummins. 1972. Cell wall composition and deoxyribonucleic acid similarities among the anaerobic coryneforms, classical propionibacteria, and strains of Arachnia propionica. J. Bacteriol. 109: 1047-1066.

JoHnson, J. L., and B. S. Francis. 1975. Taxonomy of the clostridia: ribosomal ribonucleic acid homologies among the species. J. Gen. Microbiol. 8: 229-244.

JOHNSTONE, D. B. 1974a. The genus Azotobacter. In Bergey's Manual of determinative bacteriology. 9th ed. Edited by R. E. Buchanan and N. E. Gibbons. The Williams and Wilkins Co., Baltimore, MD. pp. 254-255.

1974b. The genus Azomonas. In Bergey's Manual of determinative bacteriology. 8th ed. Edited by R. E. Buchanan and N. E. Gibbons. The Williams and Wilkins Co., Baltimore, MD. pp. 255-256.

KRIEG, N. R. 1976. Biology of the chemoheterotrophic spirilla. Bacteriol. Rev. 40: 55-115.

— 1977. Taxonomic studies of Spirillum lipoferum. In Genetic engineering for nitrogen fixation. Edited by A. Hollaender. Plenum Press, New York. pp. 463-472.

KRIEG, N. R., and P. B. HYLEMON. 1976. The taxonomy of the chemoheterotrophic spirilla. Annu. Rev. Microbiol. 30: $303-325$.

Krieg, N. R., and J. J. Tarrand, 1978. Taxonomy of the root-associated nitrogen-fixing bacterium Spirillum lipoferum. In Limitations and potentials for biological nitrogen fixation in the tropics. Edited by J. Döbereiner, R. H. Burris, and A. Hollaender. Plenum Press, New York. pp. 317-333.

Kumari, L. M., S. K. Kavimandan, and N. S. Subba Rao. 1976. Occurrence of nitrogen fixing Spirillum in roots of rice, sorghum, maize, and other plants. Indian J. Exp. Biol. 19: 638-639.

Marmur, J., and P. Doty. 1962. Determination of the base composition of deoxyribonucleic acid from its thermal denaturation temperature, J. Mol. Biol. 5: 109-118.

Neyra, C. A., J. Döbereiner, R. Lalande, and R. KNowles. 1977. Denitrification by $\mathrm{N}_{2}$-fixing Spirillum lipoferum. Can. J. Microbiol. 23: 300-305.

Okon, Y., S. L. Albrecht, and R. H. Burris. 1976a. Factors affecting growth and nitrogen fixation of Spirillum lipoferum. J. Bacteriol. 127: 1248-1254.

1976b. Carbon and ammonia metabolism of Spirillum lipoferum. J. Bacteriol. 128: 592-597.

Palleroni, N. J., R. Kunisawa, R, Contopoulou, and M. Doudoroff. 1973. Nucleic acid homologies in the genus Pseudomonas. Int. J. Syst. Bacteriol. 23: 333-339.

Pfennig, N., and H. G. TRüPER. 1974. The Rhodospirillales (phototrophic or photosynthetic bacteria). In Handbook of microbiology. Vol. I. Edited by A. L. Laskin and H. A. Lechevalier. CRC Press, Cleveland, Ohio. pp. 17-27.

1974. The genus Rhodospirillum. In Bergey's Manual of determinative bacteriology. 8th ed. Edited by R. E. Buchanan and N. E. Gibbons. The Williams and Wilkins Co., Baltimore, MD. pp. 26-29.

SCHRÖDER, M. 1932. Die Assimilation des Luftstickstoff durch einige Bakterien. Zentralbl. Bakteriol. Parasitenkd. Infektionskr. Hyg. Abt. 2, 85: 177-212.

Sebald, M., and M. VÉron. 1963. Teneur en bases del'ADN et classification des vibrions. Ann. Inst. Pasteur, Paris, 105: 897-910.

Shewan, J. M., and M. Véron. 1974. The genus Vibrio. In Bergey's Manual of determinative bacteriology. 8th ed. Edited by R. E. Buchanan and N. E. Gibbons. The Williams and Wilkins Co., Baltimore, MD. pp. 340-345.

Shinoda, S., and K. OKamoto. 1977. Formation and function of Vibrio parahaemolyticus lateral fagella. J. Bacteriol. 129: $1266-1271$.

Von Bülow, J. F. W., and J. Döbereiner. 1975. Potential for nitrogen fixation in maize genotypes in Brazil. Proc. Natl. Acad. Sci. U.S.A. 72: 2389-2393.

Wilkins, T. D., and C. B. WALkER. 1975. Development of a micro-method for identification of anaerobic bacteria. Appl. Microbiol, 30: 825-830. 